\title{
Inverted Cone Guttapercha Obturation in Open Apex: A Case Report and Review
}

Dr. Shreeshail Indi*

Senior Lecturer, Department of Conservative Dentistry, Al Badar Dental College and Hospital, OPP. Koranti hanuman Temple, Naganahalli Road, Kalaburagi - 585102, Karnataka, India

\begin{tabular}{|c|c|}
\hline DOI: $\underline{10.36347 / \text { sjds.2021.v08i01.001 }}$ & | Received: 19.12 .2020 | Accepted: 28.12 .2020 | Published: 01.01.2021 \\
\hline *Corresponding author: Dr. Shreeshe & \\
\hline Abstract & Case Report \\
\hline $\begin{array}{l}\text { Despite high success rate of endo } \\
\text { Lack of hermatic seal can lead to } \\
\text { complexes the adaptation of obtu } \\
\text { open apex was disinfected and ol } \\
\text { and bone formation were observe } \\
\text { Keywords: Open apex, Inverted }\end{array}$ & $\begin{array}{l}\text { ween } 85 \text { and } 95 \% \text {, failures can occur due to persistent infection. } \\
\text { he root canal system. The diameter of non vital open apex tooth } \\
\text { esired working length. The clinical case of reinfected non vital } \\
\text { d cone guttapercha technique. Signs of periapical tissue healing } \\
\text { N up. } \\
\text { pexification. }\end{array}$ \\
\hline $\begin{array}{l}\text { Copyright } \odot 2021 \text { The Author(s): This is } \\
\text { License (CC BY-NC 4.0) which permits u } \\
\text { author and source are credited. }\end{array}$ & $\begin{array}{l}\text { ributed under the terms of the Creative Commons Attribution } 4.0 \text { International } \\
\text {, and reproduction in any medium for non-commercial use provided the original }\end{array}$ \\
\hline
\end{tabular}

\section{INTRODUCTION}

Treating a non vital open apex cases is a challenge to clinician due to difficulty in mechanical preparation, canal disinfection and lack of tapered root canal [1].

The width of canal limits conventional mechanical preparation and fit of tapered gutttapercha points. An attempt to create apical taper in open apex cases will make thin fragile dentinal wall at cervical area eventually leading to fracture of tooth.

Over the years different treatment modalities were applied in open apex cases like custome made guttapercha, apexification, reverse cone guttapercha, thermoplastisized obturation, surgical retrogade filling, creation of immediate apical barrier by biomimitic materials and revascularization [2-5].

Irrespective of different treatment modalities factors that influence treatment outcome are diameter of open apex, thickness of root dentin, disinfection, shape of root canal, periapical tissue response to obturating material and duration of treatment. After the canal disinfection in open apex cases techniques which take less time and form immediate apical barrier have replaced time consuming calcium hydroxide apexification and surgical management.
This case report demonstrates inverted cone gutta-percha technique in a re-infected non vital open apex case.

\section{CASE REPORT}

A 30 year old male patient reported to our hospital and presented pain and swelling in relation to left maxillary central incisor, who was free from any general health problems. Patient had undergone root canal theraphy 2 years back. Painful extraoral swelling was noted over the maxillary anterior teeth area and pain on percussion was elicited. Radiographic examination revealed a large periapical radiolucency and lack of hermetic seal. Diagnosis and need of retreatment was explained to the patient. Guttapercha was retrieved from root canal and working length was estimated. The root canal was prepared using manual endodontic files cosidering the width of canal and open apex. Irrigation was done with $0.5 \%$ of sodium hypochlorite to avoid any complications at each change of instrument. Follow of patient was done for elimination of pain and swelling with idoform based calcium hydroxide intracanal medication. Considering the open apex it was decided to use inveted cone guttapercha for tug back. After taking serial radiographs with increasing number of guttapercha, no\#80 guttapercha reverse end was snuggly fitting into root canal at desired working length. Obturation was completed with cold lateral condensation technique. 2years Periodic follow up was done for signs of periapical tissue healing and bone formation. Tooth was then considered for post core and crown. 


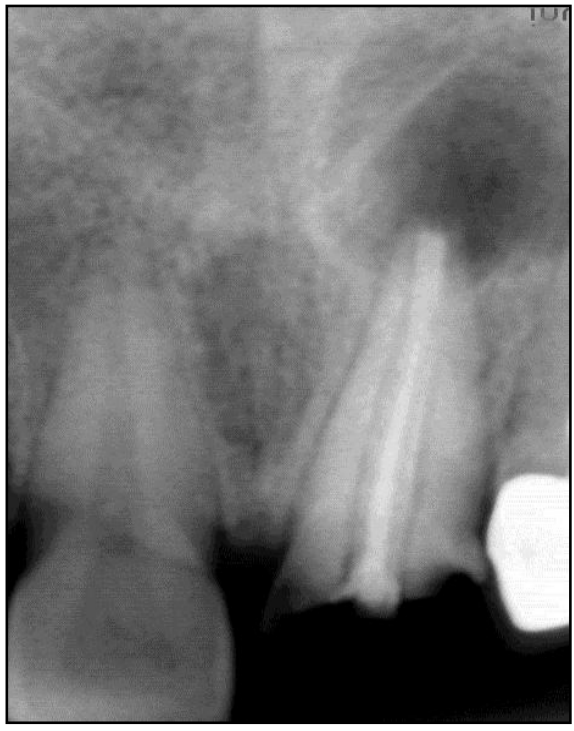

Fig-1: Initial radiograph

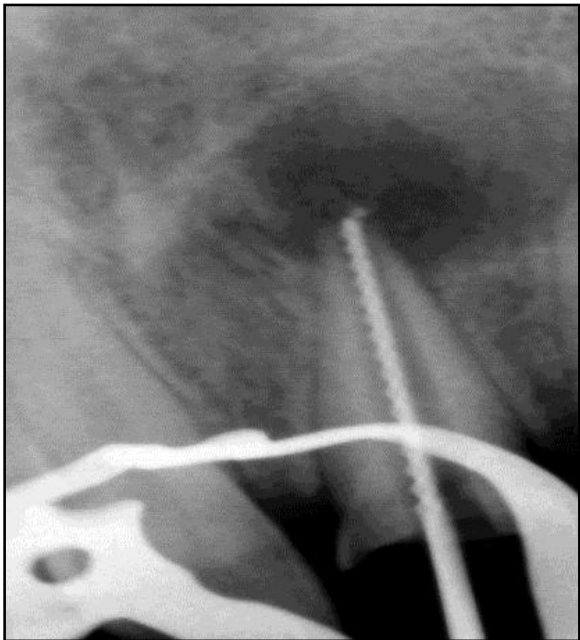

Fig-2: Working length determination

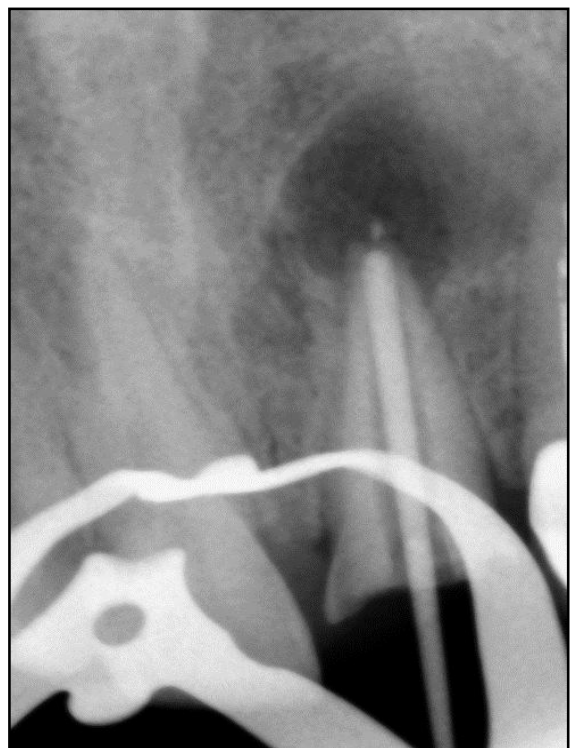

Fig-3: Radiograph showing inverted master gutta-percha cone positioned in the canal

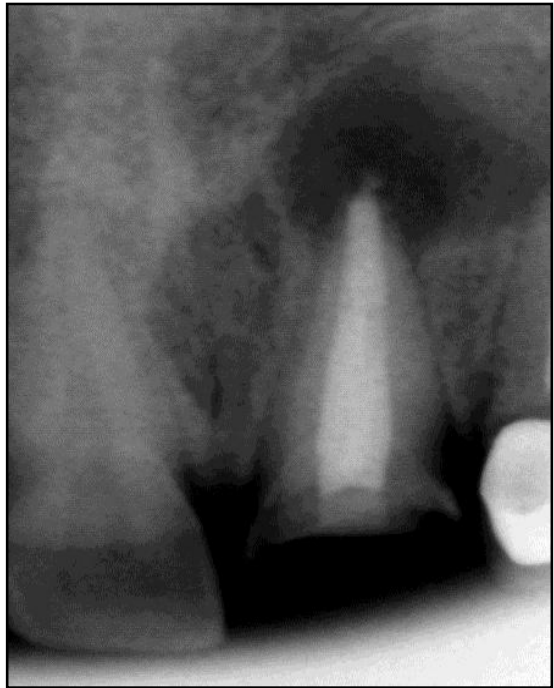

Fig-4: Postobturation radiograph

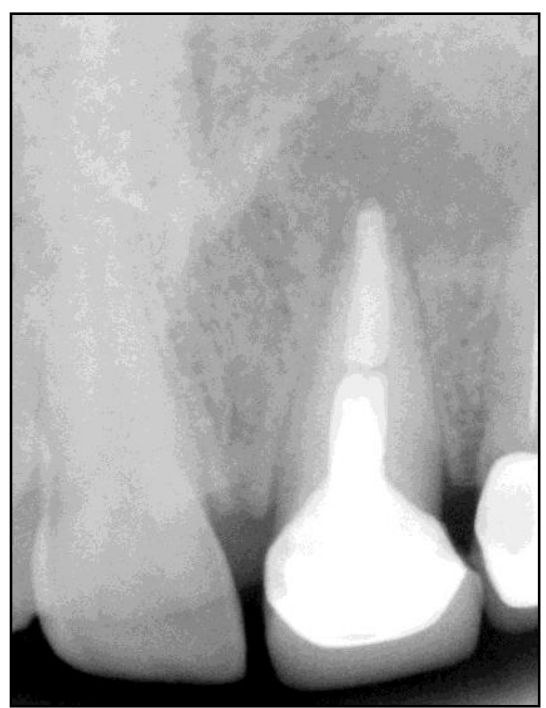

Fig-5: 2 Years follow up

\section{DISCUSSION}

Several techniques to fill the large tubular canals have been tried one of which being tailor made gutta percha in which a tailor made guttapercha is prepared of size and shape of the canal [6]. Guttapercha can be customized to the shape of the canal but it may result in apical extrusion and traumatize periapical tissues without apical barrier. During instrumentation and compaction it may lead to fracture due to thin fragile dentinal walls [7].

Apexification is defined as the process of creating an environment within the canal and periapical tissues after pulp death that allows a calcified barrier to form across the open apex of an immature root (Pitt Ford 2002).

Different materials have been used successfully, but the most favoured is a paste of $\mathrm{Ca}(\mathrm{OH}) 2$. It appears that the high $\mathrm{pH}$ of calcium hydroxide is an important factor in its ability to induce hard tissue formation. Refilling every 3-6 months is 
indicated if there is radiographic evidence of resorption of the paste or signs \& symptoms of reinfection or pathosis occur at any time during the periodic recall. An average length of time for apical barrier formation ranges from 5 to 20 months [2].

Use of $\mathrm{Ca}(\mathrm{OH}) 2$ for apexification procedures has several shortcomings such as prolonged treatment time spanning over several months and dentine exposed to $\mathrm{Ca}(\mathrm{OH}) 2$ for an extended period (6 months to 1 year) results in reduced flexural strength and lower fracture resistance [8].

With increase of apical diameter the risk of apical extrusion is more and also thermoplastisized GP may shrink after setting/cooling $[9,10]$.

Root resection and retrograde cavity preparation may further widen apical diameter making it more fragile and short root length. The outcome of surgical treatment depends on choice of retrograde filling materials which come in direct contact of periapical tissue [11].

Orthograde filling of biomimitic materials create immediate apical barrier even in presence of moisture, blood. They show satisfactory sealing ability with high success rates [12]. Short comings of these material are very long setting time and difficult manipulation [13].

Regenerative endodontic procedures are potential alternative to creation of apical barrier by intracanal obturating materials. Root canal space with free of contamination along with revascularization can regenerate vitality and apical growth leading to root end closure [14].

Revascularization procedures can be implemented in any age ranging from 9 to 18 years. Tooth consisting of apical diameter of $\geq 1 \mathrm{~mm}$ showed high success in regenerative endodontics [15].

In the above case report inverted cone guttapercha technique was used to seal the canal. Inverted cone technique was considered in this case due to average apical diameter, thick radicular dentin, immediate obturation after canal disinfection and also due to less chance of overobturation. Diameter of Inverted cone at apex can provide seal at apical third of root canal with more of gutta-percha and less of sealer [3].

\section{CONCLUSION}

Non vital Tooth with open apex consisting of average diameter, tapering canal can be considered for inverted cone gutta-percha technique obturation.

\section{REFERENCES}

1. Stewart DJ. Root canal therapy in incisor teeth with open apices. Br Dent J. 1963; 114:249-54.

2. Rafter M. Apexification: a review. Dent Traumatol. 2005 Feb; 21(1):1-8.

3. Wu MK, Groot SD, M van der Sluis LW, Wesselink PR. The effect of using an inverted master cone in a lateral compaction technique on the density of the gutta-percha fill. Oral Surg Oral Med Oral Pathol Oral Radiol Endod. 2003 Sep; 96(3):345-50.

4. Simon S, Rilliard F, Berdal A, Machtou P. The use of mineral trioxide aggregate in one visit apexification treatment: A prospective study. Int Endod J. 2007; 40:186-97.

5. Namour M, Theys S. Pulp Revascularization of Immature Permanent Teeth: A Review of the Literature and a Proposal of a New Clinical Protocol Scientific World Journal. 2014; 2014: 737503.

6. Ingle JI, Newton CW, West JD, Gutmann JL, Korzon B, Martin H. Obturation of the Radicular Space. In: Ingle JI, Bakland LK, editors. Endodontics. $5^{\text {th }} \mathrm{ed}$. India: Harcourt India Pvt Ltd; 2002. p. 571-668.

7. Reddy S, Sukumaran VG, Bharadwaj N. Tailor-made endodontic obturator for the management of Blunderbuss canal. J Conserv Dent. 2011 Apr-Jun; 14(2): 199-202.

8. Mohammadi Z, Dummer MH. Properties and applications of calcium hydroxide in endodontics and dental traumatology. Int Endod J. 2011 Aug; 44(8):697-730.

9. El Deeb ME. The sealing ability of injection-molded thermoplasticized gutta-percha. J Endod.1985 Feb; 11(2):84-6.

10. Darcey J, Roudsari RV, Jawad S, Taylor C, Hunter M.

Modern Endodontic Principles. Part 5: Obturation. Dent Update. 2016 Mar; 43(2):114-6.

11. Saxena P, Gupta SK, Newaskar V. Biocompatibility of root-end filling materials: recent update. Restor Dent Endod. 2013 Aug; 38(3):119-127.

12. Mente J, Leo M, Panagidis D, Ohle M, Schneider S, Bermejo JL, Pfefferle T. Treatment outcome of mineral trioxide aggregate in open apex teeth. Journal of endodontics. 2013 Jan 1;39(1):20-6.

13. Kaur M, Singh H, Dhillo JS, Batra M, Saini M. MTA versus Biodentine: Review of Literature with a Comparative Analysis. J Clin Diagn Res. 2017 Aug; 11(8):ZG01-ZG05.

14. de Souza Araújo PR, Silva LB, dos Santos Neto AP, de Arruda JA, Álvares PR, Sobral AP, Júnior SA, Leão JC, da Silva RB, Sampaio GC. Pulp revascularization: a literature review. The open dentistry journal. 2017;10:48-56.

15. Estefan BS, Batouty KME, Nagy MM, Diogenes A. Influence of age and apical diameter on the success of endodontic regeneration procedures. J Endod. 2016 Nov; 42(11):1620-1625. 